Tersedia online di: http://ejournal-balitbang.kkp.go.id/index.php/bawal
e-mail:bawal.puslitbangkan@ gmail.com
BAWAL wIDYA RISET PERIKANAN TANGKAP
Volume 8 Nomor 3 Desember 2016
p-ISSN: 1907-8226
e-ISSN: 2502-6410
BAWALALA
Nomor Akreditasi: 620/AU2/P2MI-LIPI/03/2015

\title{
KAJIAN KUALITAS PERAIRAN UNTUK PERIKANAN DI RAWA PENING JAWA TENGAH
}

\section{ASSESSMENT OF WATER QUALITY FOR FISHERIES IN RAWA PENING CENTRE OF JAVA}

\author{
Siti Nurul Aida* dan Agus Djoko Utomo \\ Balai Penelitian Perikanan Perairan Umum, Jl. Beringin No. 8, Mariana, Palembang, Sumatera Selatan, Indonesia \\ Teregistrasi I tanggal: 11 Juli 2014; Diterima setelah perbaikan tanggal: 13 Desember 2016; \\ Disetujui terbit tanggal: 19 Desember 2016
}

\begin{abstract}
ABSTRAK
Perairan Rawa Pening merupakan tipe perairan yang tergenang dan mempunyai arti penting bagi perikanan. Masalah utama yang ada di Rawa Pening yaitu pendangkalan karena sedimentasi dan eutrofikasi yang disebabkan pencemaran air berasal dari limbah rumah tangga, pertanian dan budidaya perikanan. Penelitian ini bertujuan untuk mengetahui tingkat kesuburan perairan dan kualitas air di Rawa Pening. Penelitian dilakukan pada bulan Mei, Juni, Agustus dan Oktober 2013. Frekuensi pengambilan contoh dilakukan empat kali yaitu pada bulan Mei, Juni, Agustus dan Oktober. Stasiun pengamatan meliputi: A. Tengah (Puteran); B. Muara sungai (Torong); C. Area KJA; D. Pemotongan eceng Gondok (tengah 1); E. Sungai keluar (Tuntang); F. Muara sungai (Muncul); G. Tidak ada pemotongan eceng gondok (tengah 2). Data tingkat kesuburan perairan dianalisis dengan metode Carlon's. Hasil penelitian menunjukkan bahwa Rawa Pening termasuk katagori perairan dengan tingkat kesuburan tinggi, nilai Thropic State Index (TSI) pada semua stasiun pengamatan berkisar antara 57,22 - 68,06. Kondisi kualitas air yang kurang baik tersebut akan merugikan perikanan, seperti kejadian kematian ikan masal, lambatnya pertumbuhan ikan dan penurunan daya dukung perairan.
\end{abstract}

Kata Kunci: Kualitas air; tingkat kesuburan; Rawa Pening

\section{ABSTRCT}

The Rawa Pening waters is a lentic water and has significance for fishery. The main problems in Rawa Pening are silting due to sedimentation and eutrophication due to water pollution from household waste, agriculture and fisheries. The study aims to examine trophic level and water quality. The research conducted on May, June, August and October 2013. There was 7 stations i.e. A. middle (Puteran); B. inlet of Torong; C. Location of aquaculture; D. locations where harvesting of water hyacinth occurred (middle1); E. outlet (Tuntang); F. inlet (Muncul); G. location where no harvest of water hyacinth (middle 2). Trophic level were analyzed by Carlon's method. The results showed that Rawa Pening waters categorized as the high eutrophication level where the Trophic State Index (TSI) was 57. 22 to 68. 06. The low water quality will be detrimentaled to fisheries, such as mass fish death, slow fish growth and also a decline of carrying capacity of ecosystem.

Keywords: Water quality; trophic state; Rawa Pening

\section{PENDAHULUAN}

Rawa Pening luasnya 2. 020 ha merupakan danau alami yang dibendung untuk keperluan irigasi dengan 9 sungai yang bermuara ke Waduk (inlet) dan 1 sungai yang keluar (outlet) yaitu sungai Tuntang. Beberapa anak sungai yang masuk ke Rawa Pening antara lain Sub-DAS Galeh, Torong, Panjang, Legi, Parat, Sraten, Rengas, Kedung Ringin dan
Ringis. Rawa Pening berada di Kabupaten Semarang Jawa Tengah dibatasi oleh empat kecamatan yaitu Ambarawa, Tuntang, Bawen dan Banyubiru. Kawasan ini terletak pada posisi geografis antara $7^{\circ} 04^{\prime}-7^{0} 30^{\prime \prime} \mathrm{LS}$ dan $110^{\circ} 24^{\prime} 46^{\prime \prime}-$ $110^{\circ} 49^{\prime} 06^{\prime \prime}$ BT (Dinas Peternakan dan Perikanan Kab. Semarang, 2007). Rawa Pening memiliki fungsi sebagai penyangga ekosistem dan menjadi habitat bagi beraneka ragam mahluk hidup (Reni, 2013 ). Pada saat ini telah 
berlangsung exploitasi sumberdaya alam yang terusmenerus, sehingga perlu adanya konservasi sumberdaya alam (Balitbang Jateng, 2004)

Masalah utama yang ada di Rawa Pening yaitu pendangkalan yang disebabkan oleh sedimentasi dan eutrofikasi yang disebabkan pencemaran air. Sedimentasi dan limbah organik yang masuk ke Rawa Pening termasuk tinggi. Pendangkalan di Rawa Pening mencapai angka 778,93 ton per tahun dengan volume material sebanyak 29,7 juta meter (Soeprobowati et al.,2010). Limbah organik berasal dari aktivitas manusia terutama dari limbah rumah tangga, pertanian dan perikanan yang mengakibatkan terjadinya eutrofikasi dan penurunan kualitas air. Secara geologi tanah di Rawa Pening merupakan tanah gambut dan sumber sulfur (S) berasal dari bahan organik yang terdekomposisi mengeluarkan asam sulfat $\left(H_{2} S\right)$, sehingga perairan menjadi asam (Sunarminto, 1980). Kondisi Rawa Pening telah banyak mengalami perubahan yang diindikasikan oleh berkembangnya tanaman akuatik yang sangat cepat, umumnya berkaitan dengan proses eutrofikasi. Pengkayaan unsur hara (eutrofikasi) dapat menyebabkan berkembangnya tanaman air, sehingga permukaan perairan tertutup eceng gondok mencapai 70 $\%$ (Dinas Peternakan dan Perikanan Kab. Semarang, 2007). Penutupan permukaan oleh tumbuhan air semakin besar prosentasenya terutama pada musim kemarau. Banyaknya sedimen yang terperangkap akar tanaman eceng gondok dan akumulasi serasah eceng gondok di dasar perairan dapat menyebabkan pendangkalan (Soeprobowati \& Suedy, 2010).

Polutan berasal dari limbah pertanian dan domestik banyak mengandung unsure $\mathrm{N}$ dan $\mathrm{P}$ yang akan menyebabkan eutrofikasi. Akumulasi bahan organik dari sungai-sungai yang mengalir ke Rawa Pening menyebabkan kandungan bahan organik menjadi tebal, perombakan bahan organik didasar perairan Rawa Pening sangat lambat (Balitbang Jateng, 2004). Perairan eutrofik memiliki kandungan unsur hara yang tinggi, perairan dangkal, tumbuhan lithoral melimpah, kepadatan fitoplankton tinggi, sering terjadi blooming alga dengan tingkat penetrasi cahaya matahari umumnya rendah (Goldman \& Horne, 1989., Henderson \& Markland 1987). Pencemaran dan pendangkalan telah menyebabkan perubahan struktur komunitas ikan Wader Ijo (Osteochilus hasselti) yang dahulu banyak terdapat di Rawa Pening sekarang sulit didapatkannya. Pencemaran dan pendangkalan juga menyebabkan fungsi ekosistem perairan, perekonomian dan kesehatan masyarakat terganggu (Utomo, et al., 2014).

Sebagian besar masyarakat di sekitar Rawa Pening kegiatannya didominasi oleh perikanan tangkap dengan jumlah nelayan 1.650 RTP dan produksi hasil tangkapan $1.000-1.200$ ton/tahun (Dinas Peternakan dan perikanan kab. Semarang, 2007). Sehingga apabila terjadi penurunan kualitas air maka akan berdampak pada hasil tangkapan nelayan. Rawa Pening juga merupakan sumber air bersih untuk keperluan sehari-hari oleh mayarakat, sehingga bila terjadi penurunan kualitas air akan berdampak langsung terhadap kesehatan masyarakat (Irianto \& Triweko, 2011). Kajian tentang kualitas perairan di Rawa Pening diharapkan dapat memberikan masukan bagi dasar pengelolaan sumber daya perairan dan perikanan.

\section{BAHANDANMETODE Tempat dan Waktu}

Penelitian ini dilakukan di perairan Rawa Pening Kabupaten Semarang Jawa Tengah, pada bulan Mei hingga Oktober 2013. Pengambilan contoh di lapangan dilakukan pada bulan Mei, Juni, Agustus dan Oktober. Pengamatan dilakukan pada tujuh stasiun yang mewakili perairan yaitu: A) Perairan tengah (Puteran): Perairan tengah yang banyak terdapat eceng gondok, B). Muara S. Torong (inlet Torong): tempat pertemuan sungai torong masuk ke perairan danau Rawa Pening, C). KJA: Perairan tempat budidaya ikan di karamba, D). Perairan tengah tempat pemotongan eceng gondok (Tengah 1), E) Out let Tuntang: Perairan yang dekat pintu keluar waduk ke sungai Tuntang. F). Muara S. Muncul (inlet Muncul) : tempat pertemuan sungai muncul masuk ke perairan danau Rawa Pening , G). Perairan tengah tidak ada pemotongan eceng gondok (Tengah 2): Perairan tengah dan tidak terdapat eceng gondok (Gambar 1).

\section{Parameter yang Diamati}

Parameter kualitas air yang diamati meliputi suhu, TDS, TSS, oksigen terlarut, kecerahan, kekeruhan, P-total, Clhorophyl-a (Tabel 1). Pemeriksaan kualitas air untuk oksigen dan suhu, secara in situdiukurtiap perbedaan kedalaman $1 \mathrm{~m}$ mulai dari lapisan permukaan hingga dasar perairan. Metoda analisis kualitas air berdasarkan APHA (1986). 


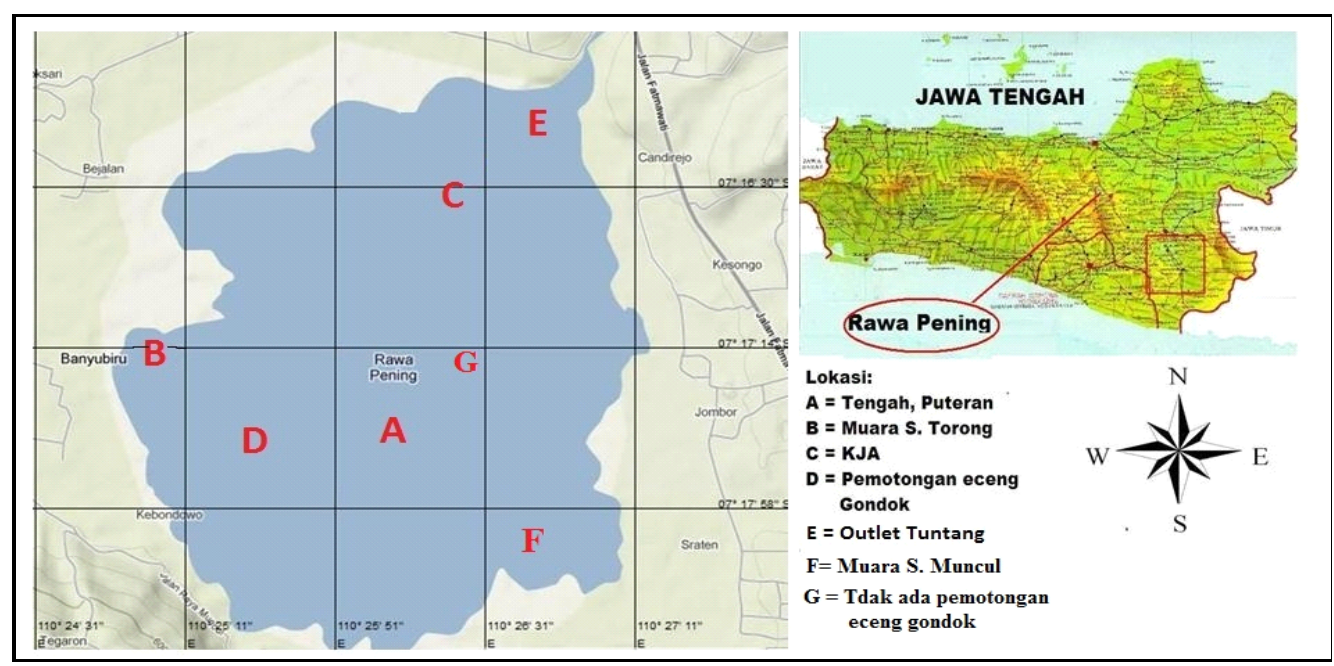

Gambar 1. Peta lokasi penelitian di perairan Rawa Pening.

Picture 1. Map of research location at Rawa Pening.

Tabel 1. Parameter dan metode analisis

Table 1. Parameters and analisys methods

\begin{tabular}{lll}
\hline Parameter/Parameters & $\begin{array}{l}\text { Satuan/ } \\
\text { Unit }\end{array}$ & $\begin{array}{l}\text { Metode dan peralatan/ } \\
\text { Equipment and Methods }\end{array}$ \\
\hline 1. Suhu & ${ }^{\mathrm{O}} \mathrm{C}$ & Insitu. Termometer \\
2. TDS & $\mathrm{mg} / \mathrm{L}$ & Insitu. TDS meter \\
3. TSS & $\mathrm{mg} / \mathrm{L}$ & Metode gravimetric \\
4. Oksigen terlarut & $\mathrm{mg} / \mathrm{L}$ & Insitu. Do-meter \\
5. Kecerahan & $\mathrm{cm}$ & Insitu. Secchi disk \\
6. Kekeruhan & $\mathrm{NTU}$ & Spectrophotometric \\
7. P- total & $\mathrm{mg} / \mathrm{L}$ & Vanadate molibdate, pectrophotometric \\
8. Chlorophyl-a & $\mu \mathrm{g} / \mathrm{L}$ & Spectrophotometric \\
\hline
\end{tabular}

\section{Analisis Data}

Untuk menggambarkan kualitas air di perairan Rawa Pening, dilakukan analisis deskriptif berupa tabulasi data grafik berdasarkan lokasi dan kedalaman perairan. Tingkat kesuburan perairan dianalisis menggunakan metoda index status trofik /trophic state index (TSI) berdasarkan Carlson's 1977 dalam Prasad \& Siddraju (2012) dengan rangkaian rumus sebagai berikut :
1) $\mathrm{TSI}-\mathrm{TP}=14,42 * \operatorname{Ln}[\mathrm{TP}]+4,15$, di mana $\mathrm{TP}=$ total $\mathrm{P}$ dalam satuan ìg/L

2) $\mathrm{TSI}-\mathrm{SD}=60-14,41 * \operatorname{Ln}[\mathrm{SD}]$, di mana $\mathrm{SD}=$ kecerahan air dalam meter

3) TSI-Chl $=30,6+9,81 * \mathrm{Ln}[\mathrm{Chl}]$, di mana Chl = klorofila dalam satuan ìg/L

4) Rataan TSI $=($ TSI-TP + TSI-SD + TSI-Chl $) / 3$

Tabel 2. Kategori status trofik berdasarkan Indeks Status Trofik Carlson

Table 2. Trophic status catagory based on the Trophic Status Index' Carlson

\begin{tabular}{|c|c|c|}
\hline $\begin{array}{l}\text { Skor/ } \\
\text { Score }\end{array}$ & $\begin{array}{l}\text { Status Trofik/ } \\
\text { Trophic } \text { Status }\end{array}$ & Keterangan/ Remarks \\
\hline$<30$ & Ultraoligotrofik & $\begin{array}{l}\text { Kesuburan perairan sangat rendah. Air jernih, konsentrasi oksigen terlarut } \\
\text { tinggi sepanjang tahun dan mencapai lapisan hypolimnion. }\end{array}$ \\
\hline $30-40$ & Oligotrofik & $\begin{array}{l}\text { Kesuburanperairan rendah, air jernih. Pada saat musim panas pada danau yang } \\
\text { dangkal dimungkinkan adanya pembatasan anoksik pada lapisan } \\
\text { hypolimnetik secara periodik. }\end{array}$ \\
\hline $40-50$ & Mesotrofik & $\begin{array}{l}\text { Kesuburan perairan sedang. Kecerahan air sedang, peningkatan perubahan } \\
\text { sifat anoksik di zona hypolimnetik selama musim panas. }\end{array}$ \\
\hline $50-60$ & Eutrofik ringan & $\begin{array}{l}\text { Kesuburan perairan tinggi. Penurunan kecerahan air, zona hypolimnetik } \\
\text { bersifat anoksik, mulai terjadi masalah tanaman air, hanya ikan-ikan yang } \\
\text { bertoleransi terhadap air hangat. }\end{array}$ \\
\hline
\end{tabular}


60-70 Eutrofik sedang Kesuburan perairan tinggi. Didominasi oleh algae hijau-biru, terjadi penggumpalan algae, masalah tanaman air sudah ekstensif.

70-80 Eutrofik berat Kesuburan perairan tinggi. Terjadi bloming algaeberat sepanjang musim panas, seperti kondisi hypereutrofik.

$>80$ Hype reutrofik Kesuburan perairan sangat tinggi. Terjadi gumpalan algae, sering terjadi kematian ikan pada saat musim panas.

\section{HASIL DAN BAHASAN}

Hasil

\section{Oksigen Terlarut dan Suhu}

Kedalaman stasiun pengamatan berkisar antara 1,5-6 m. Nilai DO terlarut berkisar antara $0,25-14,6 \mathrm{mg} / \mathrm{l}$.
Kandungan oksigen pada lapisan permukaan pada semua lokasi nilainya lebih besar $3 \mathrm{mg} / \mathrm{l}$, konsentrasi tertinggi terdapat di stasiun muara Muncul dan tengah I (perairan yang bersih dari eceng gondok) yaitu $14-14,6 \mathrm{mg} / \mathrm{L}$. Secara umum DO terlarut mempunyai kecendrungan berbanding lurus dengan kedalaman, semakin dalam perairan semakin rendah konsentrasinya (Gambar 2).

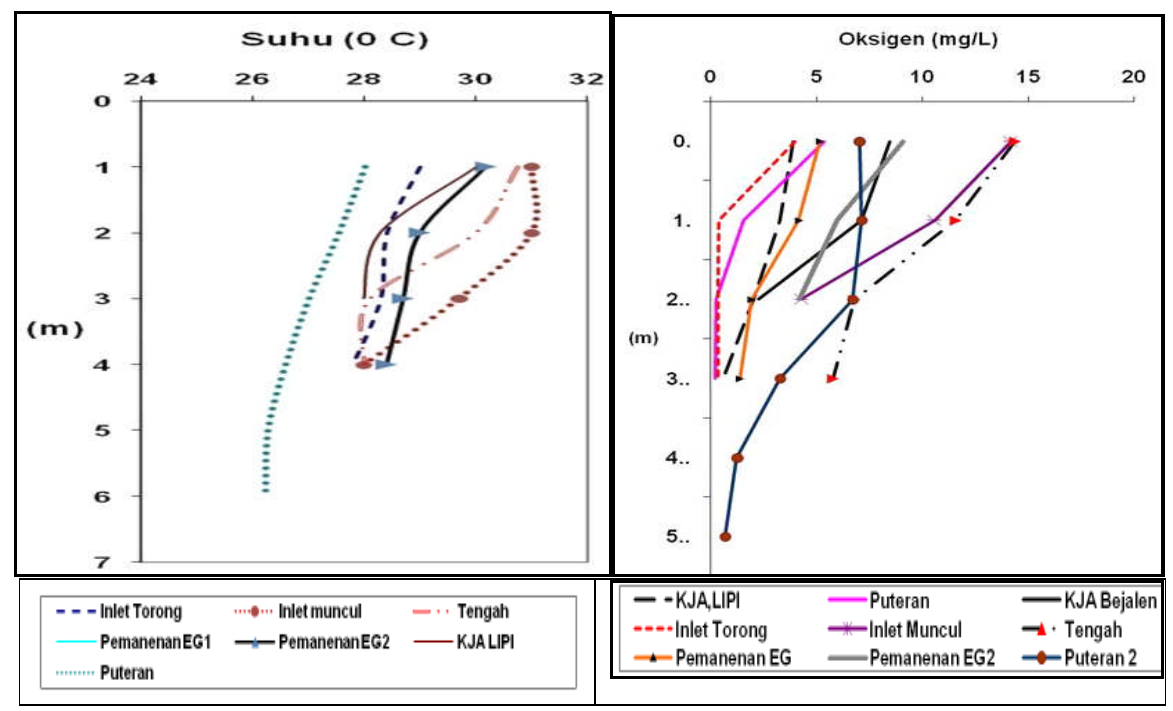

(a)

(b)

Gambar 2. Grafik suhu (a) dan DO (b) berdasarkan kedalaman di Rawa Pening.

Figure 2. Graphic of temperature (a) and DO (b) by water depth at Rawa Pening.

Catatan/Notes of: Nilai suhu dan oksigen merupakan nilai rata rata dari empat kali (sampling/ Temperature and oxygen level is the average value of four times the sampling).

Perairan yang ada pemanenan eceng gondok, dekat KJA dan inlet Torong pada kedalaman kurang dari $2 \mathrm{~m} \mathrm{DO}$ nya kurang dari $3 \mathrm{mg} / \mathrm{l}$, bahkan di inlet Torong pada kedalaman $1 \mathrm{~m}$ sudah mendekati nol. Nilai DO pada permukaan perairan berkisar antara3,93-14,6 mg/l, kedalaman 1 meter antara0,4-11,8 mg/l, kedalaman 2 meter antara 0,3-8 mg/l, dan kedalaman 3 meter antara 0,25-4,4 $\mathrm{mg} / \mathrm{l}$.

Nilai suhu berkisar antara $25-31,5^{\circ} \mathrm{C}$. Nilai tertinggi terdapat di stasiun muara Muncul, tengah I dan tengah II, yaitu $29-31,5^{\circ} \mathrm{C}$. Nilai terendah $25-27,7^{\circ} \mathrm{C}$ terdapat di stasiun Puteran. Suhu perairan semakin ke arah dasar perairan semakin rendah. Pada permukaan perairan, suhu berkisar antara $28,7-31,5^{\circ} \mathrm{C}$, kedalaman 1 meter berkisar 28,5- 30, $5^{\circ} \mathrm{C}$, kedalaman 2 meter berkisar $26-30{ }^{\circ} \mathrm{C}$, dan kedalaman 3 meter berkisar $25-29^{\circ} \mathrm{C}$ (Gambar 2).

\section{Total Disssolved Solid (TDS) dan Total Suspended Solid (TSS)}

Nlai TDS tertinggi di stasiun KJA berkisar antara 100$178 \mathrm{mg} / \mathrm{l}$, di Puteran 109-132 mg/l, di muara sungai Torong $101-148 \mathrm{mg} / \mathrm{L}$, di muara sungai muncul $108-131 \mathrm{mg} / \mathrm{l}$, di lokasi tengah I 108-134 mg/L, tengah II 106-130 mg/l,di out let didekat sungai Tuntang 104-144 mg/l. TSS di perairan Rawa Pening berkisar antara 2-49 mg/l. TSS tertinggi pada lokasi muara Muncul yaitu 12-49 mg/l, sedangkan terendah pada lokasi out let yaitu $2-8 \mathrm{mg} / \mathrm{l}$. Nilai TSS pada stasiun dekat inlet cenderung lebih tinggi bila dibandingkan stasiun lain. Pengamatan di KJA berkisar antara 5-12 mg/l. Stasiun Puteran berkisar 2-15 mg/l. Di muara sungai Torong berkisar 10-38 mg/l. Di tengah I, yaitu $10,13-10,7 \mathrm{mg} / \mathrm{l}$ dan lokasi tengah II berkisar antara 6-10 $\mathrm{mg} / \mathrm{l}$ (Tabel 3). 
Tabel 3. Nilai kecerahan, TDS, TSS, kekeruhan, TP dan klorofil-a di Rawa Pening

Table 3. Value of tranparance, TDS, TSS, turbidity, TP and chlorophyll-a at Rawa Pening

\begin{tabular}{lcccccc}
\hline \multicolumn{1}{c}{ Lokasi/Location } & $\begin{array}{c}\text { Kecerahan } \\
(\mathbf{c m})\end{array}$ & $\begin{array}{c}\text { TDS } \\
(\mathbf{m g} / \mathbf{l})\end{array}$ & $\begin{array}{c}\text { TSS } \\
(\mathbf{m g} / \mathbf{l})\end{array}$ & $\begin{array}{c}\text { Turbidity } \\
(\mathbf{N T U})\end{array}$ & TP(mg/l) & $\begin{array}{c}\text { Klorofil } \\
(\boldsymbol{\mu g} / \mathbf{l})\end{array}$ \\
\hline A. Tengah,Puteran & $62-87$ & $109-132$ & $2-15$ & $1,9-11,72$ & $0,074-0,188$ & $35,7-55.9$ \\
B. Muara. S. Torong & $64-100$ & $101-148$ & $10-38$ & $2-14,8$ & $0,060-0,080$ & $22,6-46.41$ \\
C. KJA & $50-95$ & $100-178$ & $5-12$ & $2,9-10,72$ & $0,053-0,191$ & $25-174$ \\
$\begin{array}{l}\text { D. Pemotongan e. } \\
\text { gondok (Tengah 1) }\end{array}$ & $60-91$ & $106-130$ & $6-10$ & $3,5-7,5$ & $0,053-0,079$ & $8,7-53,55$ \\
E. Out let Tuntang. & $40-97,5$ & $104-144$ & $2-8$ & $6,32-9,85$ & $0,027-0,087$ & $14,3-47,6$ \\
F. Muara. S. Muncul & $50-81$ & $108-131$ & $12-49$ & $1-5.6$ & $0,047-0,083$ & $38,1-52,36$ \\
$\begin{array}{l}\text { G. Tidak ada } \\
\begin{array}{l}\text { Pemotongan e. } \\
\text { gondok (Tengah 2) }\end{array}\end{array}$ & $67-102$ & $108-134$ & $10,13-$ & $4,4-10,7$ & $0,047-0,080$ & $29,75-48,8$ \\
\hline
\end{tabular}

\section{Kecerahan dan Kekeruhan}

Tingkat kecerahanperairan Rawa Pening berkisar antara 40-102 cm. Kisaran tertinggi terdapat di stasiun muara torong dan tengah I, yaitu $64-100 \mathrm{~cm}$ dan $67-102 \mathrm{~cm}$. Nilai terendah $50-95 \mathrm{~cm}$ di stasiun KJA dan muara sungai Muncul yaitu 50-81 cm. Kecerahan perairan di Puteran 62$87 \mathrm{~cm}$, lokasi tengah II 60-91 cm, dan out let di tuntang 40$97,5 \mathrm{~cm}$. Pada bulan Agustus dan Oktober kecerahan hanya berkisar antara 40- $82 \mathrm{mg} / \mathrm{l}$ dengan rata-rata $61 \mathrm{mg} /$ 1, di inlet sungai Muncul nilai kecerahan $50 \mathrm{mg} / \mathrm{l}$. Kekeruhan (turbidity) di perairan Rawa Pening berkisar antara 1-14,8 $\mathrm{mg} / \mathrm{l}$. Tingkat kekeruhan tertinggi di muara Torong yaitu 14,8 mgl, sedangkan terendah pada stasiun muara Muncul yaitu $1 \mathrm{mg} / \mathrm{l}$. Pengamatan di KJA berkisar antara 2,9-10,72 mg/l. Di Puteran berkisar 1,9-11,72 mg/l. Di stasiun Tengah I, yaitu 4,4-10,7 mg/l dan Tengah II: 3,5-7,5 mg/l dan stasiun out let 6,32-9,85 mg/l (Tabel 3).

\section{Total Fosfor (TP)}

Total phosfor (TP) di perairan Rawa Pening berkisar antara 0,027-0,191 mg/l. TP tertinggi pada lokasi KJA yaitu 0,053-0,191 mg/l, sedangkan terendah pada lokasi out let Tabel 4. Indek Status Trofik perairan Rawa Pening Table 4. Trophic State Index of Rawa Pening Reservoir yaitu 0,027-0,087 $\mathrm{mg} / \mathrm{l}$. Lokasi pengamatan di Puteran berkisar antara 0,074-0,188 mg/l. Di muara sungai Torong berkisar 0,060-0,080 mg/l. Di muara Muncul 0,047-0,083 $\mathrm{mg} / \mathrm{l}$. Lokasi tengah I, yaitu 0,047-0,080 mg/l dan lokasi tengah II, yaitu 0,053-0,079 mg/l (Tabel 3).

\section{Klorofil}

Klorofil-a di perairan Rawa Pening berkisar antara 8,7$174 \mu \mathrm{g} / \mathrm{l}$. Klorofil-a tertinggi pada lokasi KJA yaitu 25-174 $\mu \mathrm{g} / \mathrm{l}$, sedangkan terendah pada lokasi tengah II, yaitu 8,7$53,55 \mu \mathrm{g} / \mathrm{l}$. Lokasi pengamatan di Puteran berkisar antara 35,7-55,9 $\mu \mathrm{mg} / 1$. Di muara sungai Torong berkisar 22,646,41 $\mu \mathrm{g} / \mathrm{l}$. Di muara Muncul 38,1-52,36 $\mu \mathrm{g} / \mathrm{l}$. Lokasi tengah I, yaitu 29,75-48,8 $\mu \mathrm{g} / \mathrm{l}$ dan di out let 14,3-47,6 $\mu \mathrm{g} / \mathrm{l}$.

\section{NILAISTATUS TROFIK (TSI)}

Nilai indeks status trofik perairan perairan Rawa Pening berdasarkan metode Carlson (1977) yang didasarkan pada hasil pengukuran kecerahan perairan, kandungan total phospor dan kandungan klorofil-a. Nilai indek status trofik (TSI) pada semua stasiun menunjukkan nilai antara 57,2268,06 (Tabel 4).

\begin{tabular}{|c|c|c|c|c|c|c|c|}
\hline Lokasi/Location & Klorofil-a & TP & S. Disk & TSI & TSI & TSI & Rataan/Averange \\
\hline & $(\mu \mathrm{g} / \mathrm{L})$ & $(\mu \mathrm{g} / \mathrm{L})$ & (m) & Chlor-a & $\mathrm{TP}$ & S. Disk & TSI \\
\hline $\begin{array}{l}\text { A. Tengah,Puteran } \\
\text { B. Muara. S. Torong }\end{array}$ & 38,38 & 65,09 & 0,74 & 63,88 & 62,48 & 64,49 & 63,62 \\
\hline Inlet Torong & 25,78 & 46,85 & 0,80 & 54,80 & 53,32 & 63,53 & 57,22 \\
\hline C. KJA & 59,88 & 84,18 & 0,73 & 66,68 & 65,29 & 64,69 & 67,43 \\
\hline $\begin{array}{l}\text { D. Pemotongan } \\
\text { gondok (Tengah 1) }\end{array}$ & 27,85 & 52,77 & 0,75 & 61,64 & 60,19 & 63,99 & 61,57 \\
\hline E. Out let Tuntang. & 31,12 & 54,88 & 0,70 & 60,72 & 59,31 & 66,01 & 62,96 \\
\hline $\begin{array}{l}\text { F. Muara. S. Muncul } \\
\text { G. Tidak ada }\end{array}$ & 30,15 & 75,72 & 0,60 & 67,88 & 66,44 & 67,67 & 67,96 \\
\hline $\begin{array}{l}\text { pemotongan eceng } \\
\text { gondok (Tengah 2) }\end{array}$ & 38,97 & 68,34 & 0,66 & 66,38 & 64,93 & 66,18 & 68,06 \\
\hline
\end{tabular}




\section{Bahasan \\ Oksigen Terlarut}

Sumber oksigen di perairan berasal dari hasil proses fotosintesa tumbuhan air terutama oleh fitoplankton, juga dari difusi oksigen dari atmosfer (Effendi, 2000). Konsentrasi oksigen perairan Rawa Pening berkisar dari 0,25-14,6 mg/l , dipengaruhi oleh lokasi dan kedalaman perairan. Semakin ke arah dasar perairan kandungan oksigen semakin menurun, terutama di lokasi sekitar KJA, tempat pemanenan eceng gondok dan inlet Sungai Torong (Gambar 2). Hal tersebut disebabkan semakin ke arah dasar difusi udara dan aktivitas fotosintesa semakin mengecil, dan reduksi oksigen karena dekomposisi bahan organik didasar perairan semakin besar (Odum, 1971). Oksigen di perairan sangat penting bagi ikan untuk pernafasan, Kandungan oksigen terendah pada lapisan permukaan perairan Rawa Pening (4 mg/L) masih dapat mendukung kelayakan hidup ikan (Moyle \& Cech, 2004). Namun semakin ke dasar perairan semakin menurun hingga menjadi $0,25 \mathrm{mg} /$ L, akan membahayakan ikan bila terjadi perputaran air dari bawah ke atas (up-welling) (Aida \& Utomo, 2012).

Sisa panen eceng gondok yang dibuang ke perairan dan sisa pakan serta kotoran ikan dari KJA yang lolos ke perairan, akan membusuk mengendap didasar perairan menyebabkan kandungan oksigen pada lapisan dasar perairan rendah. Kandungan oksigen di inlet sungai Torong rendah disebabkan karena banyaknya pencemaran dari hulu sungai. Pada awal musim penghujan (Nopember - Desember), di Rawa Pening sering terjadi kematian ikan terutama ikan dalam KJA. Hal tersebut disebabkan terjadi up-welling yaitu perputaran air dari bawah ke atas dan dari atas ke bawah. Air hujan yang suhunya rendah dan berat jenisnya besar akan turun ke bawah, dan lapisan air bawah yang kadar oksigennya rendah akan naik ke atas akan menyebabkan kematian ikan (Poernomo \& Utomo, 2013). Kandungan oksigen kurang dari $3 \mathrm{mg} / \mathrm{L}$ menyebabkan pertumbuhan ikan terganggu, sedangkan bila kurang dari $2 \mathrm{mg} / \mathrm{l}$ dapat menyebabkan kematian bagi ikan (Boyd, 1988; UNESCO/WHO/UNEP, 1992). Untuk mengurangi kematian ikan secara masal pada KJA karena up-welling dapat dilakukan dengan cara menyediakan kincir angin di lokasi KJA, pergerakan air karena kincir angin akan menambah kadar oksigen dalam air. Penempatan KJA sebaiknya tidak di teluk karena sirkulasi air tidak lancar. Sebaiknya KJA ditempatkan di tengah waduk pada bagian yang dalam minimal kedalaman $11 \mathrm{~m}$, agar supaya jarak antara dasar perairan dan KJA lebih jauh (Utomo, 2015).

Kandungan oksigen terendah pada lapisan permukaan di perairan Rawa Pening pada penelitian sebelumnya yaitu 6,4 mg/L (Soeprobowati et al, 2010; Silalahi, 2010). Kandungan oksigen saat sekarang lebih rendah disebabkan karena semakin banyak pencemaran seperti sisa panen eceng gondok yang dibuang ke perairan, sisa pakan dan kotoran ikan dari KJA yang lolos ke perairan semakin banyak akan menyebabkan kandungan oksigen perairan rendah. Disamping itu limbah dari hulu sungai menuju menuju Rawa Pening semakin banyak juga menyebabkan kandungan oksigen rendah (Utomo, 2014). Danau Limboto yang mempunyai masalah perairan seperti Rawa Pening konsentrasi oksigen permukaan berkisar antara 5,1 - 6,63 mg/L (Suryono et al., 2010). Kandungan oksigen permukaan di perairan tergenang seperti danau/ waduk pada umumnya masih baik namun makin kearah dasar perairan makin menurun, sangat tergantung kandungan bahan organik di dasar perairan (Barus, 2002., Mackereth., et al 1989). Kadar oksigen di perairan Rawa Pening pada lapisan bawah lebih rendah jika dibanding perairan tergenang lainnya seperti waduk Gajah Mungkur dan Kedung Ombo. Kadar oksigen pada kedalaman 3m di perairan waduk Gajah Mungkur adalah 4-7,8 mg/L (Utomo, 2013), waduk Kedung Ombo 2,4-6,8 mg/L (Aida \& Utomo, 2012). Sedangkan kadar oksigen perairan Rawa Pening pada lapisan kedalaman yang sama hanya $0,25-4,4 \mathrm{mg} / \mathrm{L}$.

Menurut Utomo (2014), pemanenan eceng gondok di Rawa Pening yang tidak ramah lingkungan yaitu membuang bagian dari eceng gondok yang tidak dipanen (daun, akar, batang) ke perairan yang jumlahnya mencapai 24 ton/hari, akan menyebabkan kandungan oksigen menurun. Sisa eceng gondok tersebut akan membusuk mengendap di dasar perairan, menyebabkan perairan lapisan bawah kurang oksigen. Selanjutnya menurut Purnomo et al. (2013) kandungan bahan organik di dasar perairan Rawa Pening sangat tinggi yaitu $61,99 \%-74,82 \%$, akan menyebabkan kandungan oksigen di dasar perairan rendah dan proses nitrifikasi berjalan lambat. Rendahnya oksigen di dasar perairan menyebabkan dekomposisi bahan organik di dasar perairan berjalan lambat, $\mathrm{pH}$ rendah dan terbentuk zat-zat beracun $\left(\mathrm{H}_{2} \mathrm{~S}, \mathrm{NH}_{3}\right)$ yang membahayakan kehidupan ikan (Utomo et al., 2011).

\section{Suhu}

Suhu perairan dapat mempengaruhi metabolisme dan respirasi ikan, peningkatan suhu hingga di atas $30^{\circ} \mathrm{C}$ menyebabkan konsumsi oksigen meningkat terutama ikan pada KJA yang terkurung, karena peningkatan konsumsi oksigen oleh ikan tidak diimbangi dengan ketersediaan oksigen di perairan (Haslam, 1995). Suhu yang optimum bagi budidaya ikan Nila (Oreochromis niloticus) dan kebanyakan ikan air tawar daerah tropis yaitu atara 28$30^{\circ} \mathrm{C}$ (Schmittou, 1991), dengan demikian kondisi suhu permukaan perairan Rawa Pening masih berada dalam kondisi menunjang dalam kehidupan ikan. Kecenderungan semakin ke arah dasar maka suhu semakin menurun (Gambar 2). Suhu sangat dipengaruhi oleh perubahan musim, wilayah, ketinggian tempat, kedalaman air, waktu pengukuran (Effendi, 2000). 
Peristiwa up welling dapat terjadi apabila ada hujan lebat yang menyebabkan suhu permukaan lebih rendah dari bagian bawah perairan, selanjutnya lapisan perairan bagian atas turun ke bawah dan bagian bawah naik ke atas. Bahan organik di dasar perairan yang banyak gas beracun seperti $\mathrm{H}_{2} \mathrm{~S}, \mathrm{NH}_{3}$ dan $\mathrm{CO}_{2}$, terangkat ke permukaan sehingga dapat menyebabkan kematian ikan (Utomo, 2013). Pemasangan alat pengukur suhu (buoy Pluto) di sekitar KJA dapat digunakan sebagai peringatan bagi pembudidaya ikan bila terjadi penurunan suhu perairan yang mendadak (Utomo, 2015).

Bila suhu, cahaya dan nutrien dalam kondisi yang optimum maka plankton akan tumbuh dengan pesat (Vithanage, 2009). Perubahan suhu yang ekstrim dan mendadak akan menyebabkan stres bagi organisme air terutama ikan bahkan dapat menyebabkan kematian. Populasi beberapa jenis ikan di Rawa Pening terutama ikan Wader Ijo (Osteochilus vittatus) sangat berkurang salah satu penyebabnya adalah perubahan suhu perairan dari $23-24{ }^{\circ} \mathrm{C}$ menjadi $25-31,5^{\circ} \mathrm{C}$ (Bayurini, 2006). Suhu yang cocok untuk kehidupan ikan Osteochilus vittatus yaitu 22-26 C (Vidthayanon et al., 2005; Baensch \& Riehl, 1991).

\section{Total Disssolved Solid (TDS) dan Total Suspended Solid (TSS).}

TDS dapat bersumber dari antropogenic yaitu pencemaran bahan organik, berupa limbah rumah tangga atau dari KJA. TSS adalah bahan-bahan tersuspensi, terdiri dari lumpur dan pasir halus serta jasad jasad renik. Nilai TSS dan TDS sangat ditentukan oleh sedimen dan limbah yang masuk perairan melalui aliran air dan limpasan air hujan, sehingga TSS dan TDS cenderung lebih tinggi saat musim penghujan dari pada saat musim kemarau (Effendi, 2000). Nilai TSS pada stasiun dekat inlet cenderung lebih tinggi bila dibandingkan stasiun lain, hal tersebut merupakan indikasi bahwa daerah inlet banyak membawa materi hasil erosi dari daerah huluan. Menurut Hidayah et al. (2012) menyatakan bahwa nilai TSS rata rata di Rawa Pening adalah $20 \mathrm{mg} / \mathrm{L}$, sedangkan pada saat penelitian tahun 2013 di beberapa lokasi ada kenaikan terutama di inlet Torong dan Muncul mencapai 38-49 mg/L hal tersebut disebabkan karena pencemaran dan sedimentasi dari hulu sungai semakin banyak.

Menurut Nurandani (2013) laju erosi dari sub-sub DAS yang menjadi inlet danau Rawa Pening mencapai 1693 ton/tahun. Hasil erosi tersebut menyebabkan peningkatan nilai konsentrasi TSS, TDS dan kekeruhan. Perairan yang memiliki sedimentasi tinggi dapat membahayakan kehidupan ikan di lingkungan perairan. TSS dapat menyebabkan kekeruhan air dengan menghalangi penetrasi cahaya yang masuk ke dalam air, sehingga dapat mengganggu fotosintesa dan menurunkan produktivitas sumberdaya ikan (Dahuri et al., 2001 dalam Hidayah et al., 2012). Nilai TSS cenderung lebih tinggi pada lapisan dasar dari pada lapisan permukaan, karena partikel dari bahan anorganik maupun organik akan mengendap di dasar perairan. Nilai ambang batas bagi TSS di perairan tawar adalah $50 \mathrm{mg} / \mathrm{L}$, TSS yang tinggi dapat menaikan suhu perairan dan mengurangi kadar oksigen, selanjutnya akan membahayakan kehidupan ikan (Utomo et al., 2013).

Menurut Purba (2009) material tersuspensi mempunyai efek yang kurang baik terhadap kualitas air karena dapat menyebabkan menurunkan kejernihan air dan dapat mempengaruhi kemampuan ikan untuk melihat dan menangkap makanan serta menghalangi sinar matahari masuk ke dalam air. Endapan tersuspensi dapat juga menyumbat insang ikan, mencegah telur berkembang. Ketika suspended solid tenang di dasar badan air, dapat menyembunyikan telur ikan dan terjadi pendangkalan pada badan air sehingga memerlukan pengerukan yang memerlukan biaya operasional tinggi.

\section{Kecerahan dan Kekeruhan}

Kecerahan pada seluruh stasiun nilainya rendah, tertinggi hanya $102 \mathrm{~cm}$. Hal tersebut menunjukkan bahwa perairan Rawa Pening banyak terdapat materi sedimen yang larut dalam air. Menurut Novotny \& Olem (1994) perairan yang kecerahannya kurang dari $2 \mathrm{~m}$ merupakan perairan yang eutrofik. Nilai kecerahan perairan Rawa Pening terendah ada di inlet dan outlet. Menurut Trisakti et al. (2014) kecerahan perairan Rawa Pening tahun 2000 berkisar dari 100-300 cm, setelah tiga tahun kecerahan semakin berkurang disebabkan semakin bertambahnya tingkat pencemaran dan sedimentasi yang menghambat sinar matahari masuk ke perairan. Kekeruhan merupakan kebalikan dari kecerahan, diartikan sebagai intensitas kegelapan di dalam air yang disebabkan oleh bahan-bahan yang melayang. Kekeruhan perairan umumnya disebabkan oleh adanya partikel-partikel suspensi seperti tanah liat, lumpur, bahan-bahan organic terlarut, bakteri, plankton dan organism lainnya (Pujiastuti et al., 2013; Hajiali \& Pirumyan, 2014). Kekeruhan di Rawa Pening berkisar antara 1-14,8 NTU, tidak jauh berbeda dengan penelitian Hidayah, et al. (2012) yaitu 1. 3-12. 4 NTU. Kekeruhan tertinggi pada inlet dan outlet, karena inlet sungai banyak membawa sedimen dari hulu sungai sehingga perairan menjadi keruh, sedangkan kekeruhan di outlet karena materi sedimen yang terakumulasi akan terbuang ke sungai Tuntang.

Menurut Utomo et al., (2013) nilai kekeruhan di waduk paling tinggi ada di inlet dan tepian waduk, karena banyaknya partikel anorganik dari hasil erosi dari hulu sungai dan dari daratan tepi waduk. Kekeruhan yang tinggi dapat menyebabkan terganggunya sistem osmoregulasi seperti pernafasan dan daya lihat organisme akuatik termasuk ikan, serta dapat menghambat penetrasi cahaya 
ke dalam air. Peningkatan kekeruhan 5 NTU di perairan tergenang dapat mengurangi produktivitas primer sebanyak $75 \%$ (Effendi, 2000). Ikan Nilem (Osteochilus vittatus) di Rawa Pening populasinya semakin menurun, salah satu penyebabnya yaitu ikan tersebut hidup baik di perairan yang jernih, namun kondisi sekarang perairannya sudah keruh (Rochmatin et al., 2014; Utomo, 2014).

\section{Total Fosfor (TP) Dan Klorofil-a}

Konsentrasi total phosphor di perairan Rawa Pening berkisar antara 27-191,8 $\mu \mathrm{g} / \mathrm{l}$ dengan nilai rata rata adalah 61,2 $\mu \mathrm{g} / \mathrm{l}$. Menurut Novotny \& Olem (1994), perairan oligotrofik, bila kandungan total phosphor < 10 ìg/l, mesotrofik, bila kandungan phosphor total antara 10-35 ìg/l, eutrofik bila kandungan phosphor antara 35-100 ìg/ L, hipertrofik bila kandungan phosphor total > 100 ìg/l. Selanjutnya Zulvia \& Aisyah, (2013) melaporkan bahwa perairan Rawa Pening termasuk perairan yang tigkat kesuburannya sedang (mesotrofik), hal ini disebabkan karena parameter yang diambil adalah fosfat $\left(\mathrm{PO}_{4}\right)$. Untuk mengukur tingkat kesuburan perairan, apalagi perairan yang bahan organiknya tinggi sebaiknya menggunakan total fosfor (TP).

Phosfor merupakan salah satu penyebab pengkayaan unsur hara di perairan. Sumber fosfor secara alami sangat sedikit, sehingga fosfor merupakan faktor pembatas bagi kesuburan perairan. Konsentrasi fosfor yang tinggi diperairan merupakan indikasi adanya pencemaran bahan organik. Konsentrasi phosfor berasal dari limpasan air yang masuk ke waduk mengandung phosfor dari pertanian, peternakan/perikanan dan dari limbah rumah tangga (Vithanage, 2009). Keberadaan fosfor yang tinggi di perairan dapat menstimulir pertumbuhan fitoplankton dan tanaman air lainnya seperti eceng gondok, selanjutnya dapat menghambat penetrasi sinar matahari masuk ke perairan sehingga tidak menguntungkan bagi perikanan (Utomo et al.,2011).

Klorofil merupakan zat hijau daun yang sangat berperan dalam proses fotosintesis, di perairan yang mempunyai klorofil adalah fitoplankton. Banyaknya nilai klorofil bergantung pada banyaknya fitoplankton di perairan, dan banyaknya fitoplankton sangat ditentukan oleh kandungan nutrien di perairan terutama fosfor. Menurut Novotny \& Olem (1994), perairan oligotrofik bila kandungan klorofil < 4 ìg/L, mesotrofik bila kandungan klorofil antara 4-10 ìg/L, eutrofik bila kandungan klorofil >10 ìg/L. Kandungan klorofil, secara umum perairan Rawa Pening sudah masuk katagori perairan eutrofik (kesuburan tinggi). Hal ini dikarenakan jumlah fitoplankton sudah cukup tinggi yang disebabkan karena adanya pengkayaan unsur hara (eutrofikasi) terutama unsur fosfor di perairan (Utomo et al., 2010). Perairan yang eutrofik berpotensi untuk berkembang algae biru Mycrocystis sp. jenis algae ini merupakan plankton yang beracun. Jenis racun Microcystine yang ada pada plankton tersebut bila termakan oleh ikan atau binatang lainnya maka akan menimbulkan kelumpuhan syaraf. Jenis plankton tersebut tidak dapat dimanfaatkan oleh ikan, bahkan merugikan perikanan (Lindon \& Heickary, 2009 dalam Utomo et al., 2011).

\section{Nilai Status Trofik (TSI)}

Nilai indeks status trofik perairan Perairan Rawa Pening berdasarkan metode Carlson (1977) yang didasarkan pada hasil pengukuran kecerahan perairan, kandungan total phospor dan kandungan klorofil-a dapat dilihat dalam Tabel 4. Nilai indek status trofik (TSI) pada semua stasiun menunjukkan nilai antara 57,22 - 68,06, maka Perairan Rawa Pening sudah termasuk dalam katagori mempunyai tingkat kesuburan eutrofik (tingkat kesuburan tinggi). Tingkat kesuburan yang tinggi disebabkan bahan organik yang berasal dari limbah rumah tangga, pertanian, perikanan dan sisa panen eceng gondok yang dibuang ke perairan.

Tingkat kesuburan yang tinggi di Rawa Pening menyebabkan berkembangnya eceng gondok yang telah menutup luas perairan hingga $70 \%$ (Balitbang Prov. Jateng. 2004). Gulma air tersebut berdampak terhadap pendangkalan, pengurangan volume dan luasan perairan yang menyebabkan daya dukung perairan untuk perikanan semakin berkurang. Sisa pemanenan eceng gondok berupa akar dan batang yang dibuang ke perairan (24 ton/hari) juga menyebabkan pendangkalan dan penurunan kualitas air, masalah tersebut berdampak terhadap pertumbuhan ikan menjadi lambat dan kurus. (Aida, 2015; Utomo et al., 2014; Puspaningdiah et al., 2014).

\section{KESIMPULANDANSARAN Kesimpulan}

Nilai kesuburan perairan di semua stasiun pengamatan di Rawa Pening sudah pada tingkat kesuburan yang tinggi (TSI antara 57,22 - 68,06), kecerahan sangat rendah tertinggi hanya $102 \mathrm{Cm}$, total fosfor rata rata sudah tinggi yaitu 61,2ìg/l menunjukan perairan sudah eutrofik sehingga eceng gondok berkembang sangat pesat dan sulit dikendalikan. Ada kenaikan nilai TSS terutama di inlet Torong dan Muncul yaitu pada tahun 2012 sebesar 20 $\mathrm{mg} / \mathrm{L}$ dan tahun 2013 menjadi 38 - $49 \mathrm{mg} / \mathrm{L}$. Kandungan oksigen pada kedalaman $2 \mathrm{~m}$ di beberapa lokasi (inlet $\mathrm{T}$ tororong, KJA, pemanenan eceng gondok) rendah yaitu $0,3-2,4 \mathrm{mg} / \mathrm{L}$. Kondisi kualitas air yang kurang baik tersebut akan menghambat pertumbuhan ikan, sering terjadi kematian ikan bila terjadi upwelling, mengganggu pernafasan ikan karena insang ikan tersumbat oleh sedimensita, menurunnya populasi ikan Wader Ijo (Osteochilus vittatus) dan daya dukung perairan untuk perikanan semakin berkurang. 


\section{Saran}

1. Harus dilakukan pengerukan bahan organik yang mengendap di dasar perairan selanjutnya digunakan untuk pupuk organik. Agar kandungan oksigen di dasar perairan tidak terlampau rendah

2. Sisa panen eceng gondok yang jumlahnya mencapai 24 ton/hari harus dibuang ke luar perairan, untuk mengurangi eutrofikasi.

\section{DAFTAR PUSTAKA}

Aida, S.N., \& Utomo, A.D. (2012). Tingkat kesuburan perairan Waduk Kedung Ombo. BAWAL.Jurnal Widya RisetPerikanan Tangkap Jakarta. 4(1), 59-66.

Aida, S.N. (2015). Biological aspects and growth pattern of bonylip barb (Osteochilus vittatus) In Rawa Pening Reservoar. Proceeding. International Symposium on Marine and Fisheries Research (p. 17-29). Jogyakarta. ISMFR_UGM: II (AQ-03).

APHA, (1986). Standardmethods for the examinations of water and wastewater (p. 986). APHA inc, Washington DC.

Balitbang Prov. Jateng. (2004). Studi optimalisasi potensi di kawasan Rawa Pening (p. 15). Bekerjasama dengan Fakultas Teknik, UNDIPSemarang.

Baensch, H.A., \& Riehl, R. (1991). Aquarien atlas (p. 1104). Bd. 3. Melle: Mergus, verlag für Natur-und Heimtierkunde, Germany.

Barus, T.A. (2002). Pengantar Limnology (p. 164). Direktorat Jendral Pendidikan Tinggi, Jakarta.

Boyd, C. E. (1988). Water quality in warm water fish ponds (p. 359). Fourth printing. Auburn University Agriculture Experiment Station. Alabama. USA.

Bayurini, D. H. (2006). Hubungan antara produktivitas primer fitoplankton dengan distribusi ikan diekosistem perairan Rawa Pening Kabupaten Semarang (p. 95). Skripsi. Fakultas MIPA. Universitas Negeri Semarang.

Rochmatin, S. Y., Solichin, A., \& Saputra, S. W. (2014). Aspek pertumbuhan dan reproduksi ikan nilem (Osteochilus hasselti) di perairan Rawa Pening Kecamatan Tuntang Kabupaten Semarang. Diponegoro. Journal of Maquares Management of Aquatic Resource.3(3), 153-159.

Dinas Peternakan dan Perikanan Kab. Semarang, (2007). Data Statistik Perikanan Kabupaten Semarang (p. 47). Semarang.

Effendi, H. (2000). Telaahan Kualitas Air (p. 259). Jurusan MSP Fak. Perikanan dan Kelautan IPB Bogor.
Goldman, C.R., \& Horne, A. J. (1983). Limnology (p. 464). Mc. Graw Hill International Book Company.

Haslam, S. M. (1995). Riverpollution and ecological perspective (p. 253). John Wiley and Sons. Chichester, UK.

Hajiali, P., \& Pirumyan, G.P. (2014). Evaluation of turbidity and color removal in treatment of wastewater containing resistant pollutants with ozonation. International Journal of Environment Systems Science and Engineering. Elsevier. 9, 8-12.

Henderson, S., \& Markland, H. R. (1987). Decaying Lakes (p. 254). John Wiley and Sons Ltd. Chichester.

Hidayah, A. M., Purwanto \& Soeprobowati, T. R. (2012). Kandungan Logam Berat Pada Air, Sedimen dan Ikan Nila (Oreochromis niloticus Linn) (p. 95-101). Di Karamba Danau Rawa Pening. Prosiding Seminar Nasional Pengelolaan Sumberdaya Alam dan Lingkungan Semarang.

Irianto, E.W., \& Triweko. (2011). Eutrofikasi wadukdan danau, permasalahan, persoalan, dan upaya pengelolaan (p. 90). Pusat Penelitian dan Pengembangan Sumberdaya Air. Jakarta.

Mackereth, F.J.H., Heron, J., \& Talling, J.F.(1989). Wateranalysis freshwater biological association (p. 120). Cumbria, UK.

Moyle, P. B., \& Cech, J. J. (2004). Fishes, an introduction to ichthyology (p. 726). Prentice Hall, Upper Saddle River, NJ, USA.

Novotny, V., \& Olem, H. (1994). WaterQuality (p. 1054), prevention, identification, and management of diffuse polluition. Van Nostrans Reinhold. New York.

Nurandani, P. (2014). Pengolahan data penginderaan jauh untuk pemetaan TSS di danau Rawa Pening Jawa Tengah (p. 722731). Prosiding Semnaskan Pengederaan Jauh.

Odum, E. P. (1971). Fundamentals of ecology (p. 486). Third Edition Saunders College Publishing. Rinehart and Winston.

Poernomo, A., \& Utomo, A.D. (2013). Arah dan Kebijakan Pengembangan Perikanan di Danau Rawa Pening (p. 11). MakalahUtama "Workshop Penyelamatan EkosistemDanau Rawa Pening” di Semarang tanggal 13 Juni 2013.

Prasad,A. G. D., \& Siddraju. (20120. Carlson's trophic state index for the assessment of trophic status of two Lakes in Mandya distric. International Journal of Advances in Applied Science Reseacrch. Pelagia ResearchLibrary. Coden, USA.3(5), 29912996.

Purnomo,P.W., Soedarsono,P., \& Putri, M. N. (2013). Profil vertical bahan organic dasar perairan dengan latar belakang pemanfaatan berbeda di Rawa Pening. Journal of 
Management of Aquatic Resources. Fakultas Perikanan dan Ilmu Kelautan, UNDIP-Semarang. 2(3), 27-36.

Pujiastuti, P., Ismail, B., \& Pranoto. (2014). Kualitas dan beban pencemaran waduk Gajah Mungkur Jawa Tengah. Jurnal Ekosains. 5(1), 59-75.

Purba, M. E. K. (2009). Analisa kadar total (p. 45). Suspended Solid(TSS), Amoniak ( $\mathrm{NH}_{3}$ ), Sianida(CN), dan Sulfida $\left(\mathrm{S}^{2}\right)$ Pada limbah cair BAPEDALDASU. Skripsi. Dep. Kimia. Fakultas MIPA. USU.

Puspaningdiah, M., Solichin,A, \& Ghofar,A. (2014).Aspek biologi ikan Gabus (Ophiocephalus striatus) diperairan Rawa Pening Kabupaten Semarang. Diponegoro Journal of Maquares Management of aquatic resources. 3(3), 75-82.

Reni, A.R. (2013). Status Trofik Danau Rawa Pening dan Komposisi Ikan yang ada di dalamnya (p. 65). Skripsi. Program Studi Pendidikan. Universitas PGRI Semarang.

Rochmatin, S. Y., Solichin, A., \& Saputra, S. W. (2014). Aspek pertumbuhan dan reproduksi ikan Nilem (Osteochilus hasselti) di perairan Rawa Pening Kecamatan Tuntang Kabupaten Semarang. Diponegoro Journal of Maquares Management of Aquatic Resource.3(3), 153-159.

Schmittou, H. R. (1991). Budidaya keramba (p. 126). Suatu Metode Produksi Ikan di Indonesia. Puslitbang Perikanan dan Auburn University. Jakarta.

Silalahi, J. (2010). Analisis kualitas air dan hubungannya dengan keanekaragaman vegetasi akuatik di perairan Balige Danau Toba (p. 100). Thesis. Sekolah Pascasarjana, Universitas Sumatera Utara, Medan.

Sunarminto. (1980). Beberapa sifat gambut di Rawa Pening (p. 120). Tesis. Fakultas Pertanian Universitas Gajah Mada. Jogyakarta.

Soeprobowati, T. R., Tandjung, S. D., Sutikno, Hadisusanto, S., \& Gell,P.(2010). Stratigrafi diatomDanau Rawa ening: Kajian paleolimnologi sebagai landasan pengelolaan danau (p. 102115). Prosd. Seminar Nasional Limnologi V.

Soeprobowati, T. R., \& Suedy, S. W.A. (2010). Status trofik danau Rawa Pening dan solusi pengelolaannya. Jurnal Sains \& Matematika. Jurusan Biologi FMIPA Universitas DiponegoroSemarang. 18(4), 158-169.

Suryono, T., Sunannisari, S , Mulayana, E., \& Rosidah. (2010). Tingkat kesuburan dan pencemaran danau Limboto, Gorontalo. Pusat Penelitian Limnologi-LIPI. Bogor. Oseanologi dan Limnologi di Indonesia. 36(1), 49-61.

Trisakti, B., Suwargana, N., \& Cahyono, J. S. (2014). Pemanfaatan data pengenderaan jauh untukmemantau parameter ekosistem danau Rawa Pening (p. 393- 402). Prosiding Semnaskan Pengederaan Jauh.

UNESCO/WHO/UNEP. 1992. Waterquality assesments (p. 585). Edited by Chapman, D. Chapman and Hall Ltd., London.

Utomo, AD., Ridho, M. R., Putranto, D. D. A., \& Edward Saleh. (2010). The water quality assessment at gajah mungkur reservoir (p. 123-133). Proceeding International Conference on Indonesian Inland Waters II. Research Institute for Inland Fisheries.

Utomo, A.D., Ridho, M. R., Putranto, D. D.A., \& Saleh, E. (2011). Keanekaragaman Plankton dan Tingkat Kesuburan Perairan di Waduk Gajah Mungkur. BAWAL. Jurnal Widya Riset Perikanan Tangkap. Jakarta. 3(6), 415-422.

Utomo, A.D. (2013). Penentuan Daya Dukung Perairan Untuk Budidaya Ikan pada Keramba Jaring Apung di Waduk Gajah Mungkur (p. 166). Disertasi. Program Pascasarjana Universitas Sriwijaya Palembang.

Utomo, A.D., Ridho, M.R., Putranto, D.D.A., \& Edward Saleh. (2013). Saedimentation rate in gajah mungkur reservoir, Central Java Indonesia. International Journal of Development Research.India.3(04), 001-004.

Utomo,A.D.,Aida, S.N.,Hidayah, T.,Ali, M.,Hamalia, E.D. (2014). Biologi dan dinamika populasi beberapa jenis ikan di Rawa Pening Jawa Tangah (p. 124). Laporan Teknis. Balai Penelitian Perikanan Perairan UmumPalembang.

Utomo, A. D. (2014). Pengaruh cara pemanenan eceng gondok yang tidak ramah lingkungan terhadap kualitas air di Rawa Pening. Prosiding Semnaskan UGM XI. Hasil Penelitian Perikanan dan Kelautan. Jogyakarta. MA, (13), 55-62.

Utomo, A.D., \&Aida, S. N. (2015). Daya Dukung Perairan Untuk Budidaya Ikan pada Keramba Jaring Apung di Waduk Kedung Ombo Jawa Tengah. Prosiding Seminar Nasional Tahunan XII. Hasil Penelitian Perikanan dan Kelautan. Jogyakarta.pMS (04), 357-365.

Vithanage, I. C. B. (2009). Analisis of Nutrien Dynamics in Roxo Catchment Using Remote Sensing Data and Numerical Modeling (p. 103). Disertasi. International for Geo-Information Science and Earth Observation Enscede, the Netherlands.

Vidthayanon, C., Termvidchakorn, A., \& Pe, M. (2005). Inland fishes of Myanmar (p. 160). Southeast Asian Fisheries Development Center.

Zulvia, N., \&Aisyah, (2013). Status trofik perairan Rawa Pening ditinjau dari kandungan unsur hara $\mathrm{NO}_{3}, \mathrm{PO}_{4}$ dan Chlorofila. BAWAL, Widya Riset Perikanan Tangkap. Jakarta. 5(3), 189-199. 